\title{
段落ち部近傍の底面せん断力 \\ BED SHEAR STRESS CAUSED BY THE FREE OVERFALL
}

\author{
片 山道 夫**福 井吉 孝**.吉 川秀 夫*** \\ By Michio KATAYAMA, Yoshitaka FUKUI and Hideo KIKKAWA
}

\section{1.はじめに}

開水路の段落水流は, 流線が急激に曲がるため, いわ ゆる急変流となる.この水理特性を明らかにするため に,さまざまな研究がなされてきている，たとえば，N. Rajaratnam $5^{1)}$ は, 水面形状, 圧力分布, 流速分布, 底 面のせん断力分布等を実験より求めて㧍り, H. Rouse ${ }^{2)}$ は, 流れを Fr 数別に整理し, 水面形状の特性づけを 行い, さらに, brink depth と critical depth の比が 0.715 となることを示している. 岩崎 ${ }^{3)}$ は, ナップの形 状に関する実験式を与えている. また，R. Southwell ら ${ }^{4)}$ や. Markland ${ }^{5)}$ はポテンシャル流とみなして, ラ プラスの方程式をリラクゼーションによって解き, 流線 流速を求めている. しかし, これらの研究は滑面固定床 の場合にとどまり, 実用上の見地からは, より一般的な 場合の水理特性を知る必要がある.

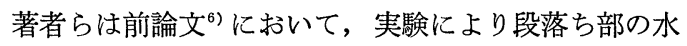
理特性を明らかにすることを試みたが，本論文ではその 結果に基づき, ポテンシャル流としての解析を行い, 実 験結果と比較し, 段落ち部の水理特性を解明する. 特に 底面のせん断力分布に着目し, その合理的な解析手法に ついて検討を行ら.すなわち, ポテンシャル流としての 解析から得られる結果と, 境界層方程式を組み合わせる ことにより, 底面のせん断力を近似的に算出しようとす る.さらに, 移動床段落ち部にこの手法を適用し, 段落 ち部上流の平衡河床形状の推定を試みる.

\section{2. 実験および実験結果}

前報 ${ }^{6)}$ に示した, 幅 $37 \mathrm{~cm}$ の水路における固定床実験

* 正会員 工修 日本道路公団 (前- 早稲田大学大学院前 期課程)

** 正会員 工修 東洋大学講師 工学部土木工学科

*** 正会員 工博 早稻田大学教授 理工学部土木工学科
表-1 実 験 条 件

\begin{tabular}{c|c|c|c|c|c}
\hline Run & $Q(l / \mathrm{s} \cdot \mathrm{m})$ & $I$ & $\mathrm{Fr}$ & $k_{s}(\mathrm{~cm})$ & 備 考 \\
\hline 1 & 33.8 & $2.7 \times 10^{-8}$ & 0.9 & & 滑 面 \\
2 & 33.8 & $7.0 \times 10^{-8}$ & 1.4 & & 滑 面 \\
3 & 33.8 & $1.6 \times 10^{-8}$ & 0.5 & 0.367 & 桡粗度 \\
4 & 33.8 & $7.0 \times 10^{-8}$ & 1.0 & 0.367 & 栈粗度 \\
5 & 16.8 & $1.0 \times 10^{-8}$ & 0.4 & 0.125 & 移動床 \\
\hline
\end{tabular}

のほかに, 幅 $5 \mathrm{~cm}$, 長さ $200 \mathrm{~cm}$ の可変勾配, 長方形断 面水路の末端にせきを設け, 河床材料として, 直径 0.2 $\mathrm{cm}$, 比重 2.5 の球形ガラスビーズを, 水路下流端せき 頂まで 水路内に一様に敷きつめ, 上流端より給砂を行 い, 移動床実験を行い, 平衡水路床形状を測定し, さら に, 路床をその形状のままに固定して, 給砂をしないで 同じ流量を流して, 流速分布, 底面せん断力を 測定し た.なお，本論文に用いた実験例は 5 ケースであり，そ の実験条件を 表一1 に示す. 圧力, せん断力の 測定に は, 静圧管および総圧管を用い, せん断力の算定は, 滑 面の場合, プレストンの手法 ${ }^{7}$, 粗面の場合, 流速分布 の測定より求めた. 水面形状, 圧力分布, 流速分布, 世 ん断力分布等の実測結果は前報に示した. その概要は次 のとおりである。

brink depth と critical depth の比は, 河床勾配と限 界勾配の 比により変化し, 滑面の場合のナップの 形状 は，段落ち部上流の等流とみなせる点で $F r<1$ であ る流れの場合に, 岩崎の実験式とよく一致する. 流線に 直角方向の静圧分布は, 段落ち部上流の等流状態におけ る静水圧分布から, 段落点に近づくにつれて静水圧分布 よりやせていき, 段落点では底面の静圧はゼロとなる. 水深方向の流速分布も, 全体としては対数分布則からは ずれ，段落ち部に近づくにつれてポテンシャル流として の流速分布に近づくが，底面近傍には対数分布則とみな せる層が存在する. 底面のせん断力は, 段落ち部に近つ くにつれて増加する. 


\section{3. 流線網の決定}

著者らが用いた，リラクゼーション法による流線網の 決定法の概略を示す.

段落ち部におけるポテンシャル流を 図一1(a) に示す 座標系 (5゙表わし，次の仮定を行う。

i ) $\mathrm{AE}$ は段落点 $\mathrm{D}$ から十分に遠く, 水深 $h$ をとり, 静水圧分布をなし, 流速はAEに沿って一様に $U$ である.

ii） $\mathrm{BC}$ は直線であり， BC に沿った静圧はゼロであ り, 流速も一様である.
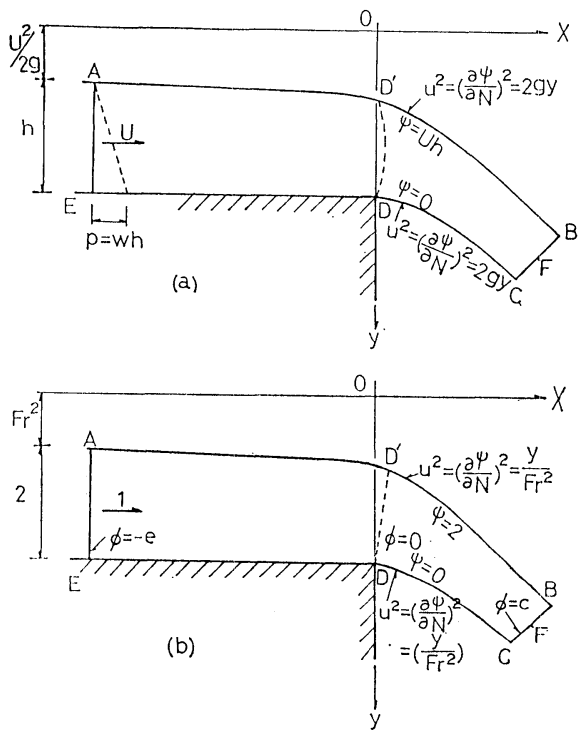

図一1 段落ち部座標系

Markland $^{5}$ ) に従い，図一1 (a) の各值を $h / 2$ を用い て無次元化すると，図一1 (b) のようになる.ここで， 流関数 $\psi$ は流線に沿って一定であり, $\mathrm{AB}$ に沿っては $\phi=2, \mathrm{CE}$ に沿っては $\phi=0$ とする．以上の点をふま え, 以下に示す 2 通りの方法で流線網を決定した. 第 1 の方法は, 実験により知られた自由水面の形状を, 境界 条件として用い， $x-y$ 平面上にあらか心゙め定められた 格子点における $\phi, \psi$ の值をプラスの方程式

$$
\frac{\partial^{2} \phi}{\partial x^{2}}+\frac{\partial^{2} \phi}{\partial y^{2}}=\frac{\partial^{2} \phi}{\partial x^{2}}+\frac{\partial^{2} \psi}{\partial y^{2}}=0 \text {. }
$$

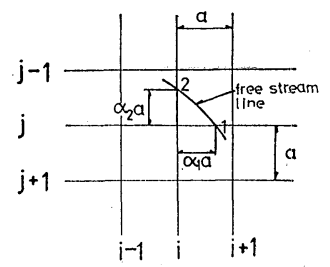

を用いてリラクゼーション 法によって解くものであ る.このとき，図一2 に示 すような, 境界曲線に近い 内側の点 $(i, j)$ における $\phi$ に関するリラクゼーショ 图一2 $\boldsymbol{x}-\boldsymbol{y}$ 平面 ン法の残差 $R_{0}$ は,

$$
R_{0}=\frac{2}{\alpha_{1}\left(1+\alpha_{1}\right)} \phi_{1}+\frac{2}{\alpha_{2}\left(1+\alpha_{2}\right)} \psi_{2}
$$

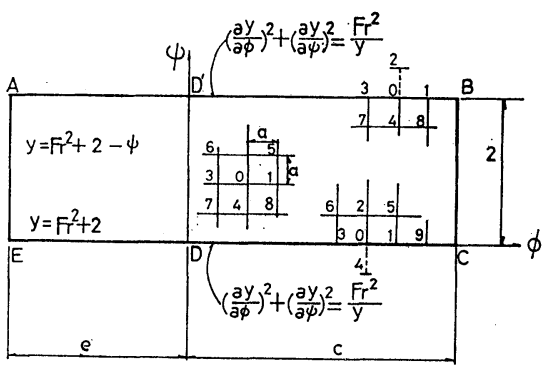

図-3 $\phi-\phi$ 平面 $+\frac{2}{1+\alpha_{2}} \psi(i, j+1)-\frac{2\left(\alpha_{1}+\alpha_{2}\right)}{\alpha_{1} \alpha_{2}} \psi(i, j)$

$\psi_{1}$ : 点 1 の $\psi$ の值, $\psi_{2}$ : 点 2 の $\phi$ 值 となり, 各格子点の $\phi$ の值は, それぞれの $R_{0}$ をゼ口 にするように修正することにより求められる.

第 2 の方法は Markland ${ }^{5)}$ が提案したものであり， $\mathrm{AE}$ に颃いて,

$$
\mathrm{Fr}=U / \sqrt{g h} \geqq 1
$$

のときに，図一 3 に示すような $\phi-\phi$ 平面上の格子点に おける $x, y$ の值をラプラスの方程式

$$
\frac{\partial^{2} x}{\partial \phi^{2}}+\frac{\partial^{2} x}{\partial \phi^{2}}=\frac{\partial^{2} y}{\partial \phi^{2}}+\frac{\partial^{2} y}{\partial \phi^{2}}=0
$$

を用いてリラクゼーション法によって解くものである. この方法では, 図一 3 に扔て, $\phi-\phi$ 平面の $\mathrm{AB}, \mathrm{CD}$ の境界条件を与える 必要がなく, 次式で示される残差 $R_{0}$ をゼロにすることにより，自動的に決定される．

$$
\begin{aligned}
R_{0}= & y_{1}+y_{3}+2 y_{4}{ }^{2}-4 y_{0} \\
& \pm\left\{\frac{4 a^{2} \mathrm{Fr}^{2}}{y_{0}}-\left(y_{1}-y_{3}\right)^{2}\right\}^{1 / 2}
\end{aligned}
$$

$y_{0}, y_{1}, y_{2}, y_{3}, y_{4}$ : 各格子点の $y$ の值 すなわち，DE の境界条件は既知であるので，ナップ末 端の $\mathrm{F}$ 点の $y$ 座標 $y_{F}$ を, 式 (5) による $R_{0}$ をゼ口 にするように与えたとき，水面形状が自動的に定まるの がこの方法の特徴である.

この 2 つの方法のうち, 前者は精度よく流線網を描く ことができるが，実験その他により，自由流線をあらか じめ知る必要がある.一方, 後者は自由流線を与える必 要はないが, $\mathrm{CD}, \mathrm{DE}$ 間の格子点数が不適当な場合, 計算が収束しにくく, 精度が悪くなる. 本論文では, せ ん断力などの流れの内容を調べるために，精度のよい前 者を用いるが，水面形のわからない場合の推定のために は後者の方法を用いる必要がある.

\section{4. 底面せん断力の算定}

流線網の計算結果を用いて

$$
\tau_{0} \propto(d \phi / d x)^{2} y=0
$$




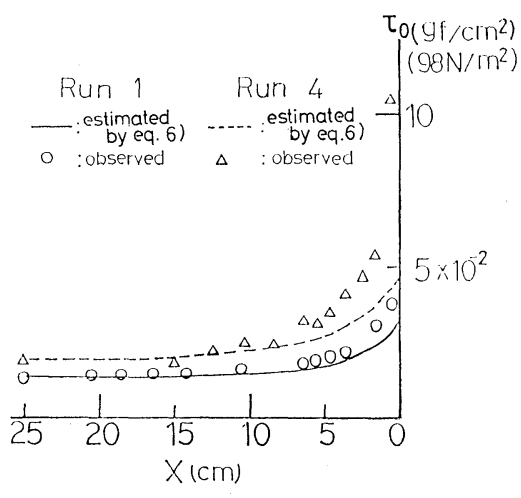

図-4 底面せん断力縦断面内分布 (1)

の関係を実測値と比較したものを 図一4 に示す ${ }^{6)}$. 図一 4 より, 式 (6) は底面せん断力 $\tau_{0}$ の分布の傾向は示し 得るものの, 粗面の場合に, 実測值とのずれが大きく, $\tau_{0}$ の算定式としては不十分であることがわかる. そこ で，著者らは，ポテンシャル流に境界層方程式を組み合 わせることにより，底面せん断力を算出することを試み た.

今の場合には，本質的には境界層内で鉛直力が働く場 合について Kármán の方程式に代わるべき式を考える べきであるが，これは，元々の Navier-Stokes の式に なってしまうので，これを条件に応じて解くことは非常 に困難である。しかし，実際に生じている境界層流れの 境界条件を 適切に選ぶなら, Kármán の運動量方程式 を導いた条件に適合させることができ，その Kármán の式を用いて，底面のごく近傍での流れを解こうとする 試みが可能となる。ここで用いた手法は，Kármán の 運動量方程式の仮定，すなわち，(i) 境界層内で圧力は 樑さ方向に変化しない，言い換えれば，流れと直角方向 には，力が働かない（ii）境界層外縁では，せん断力は 働かない．に相応した流れの場を想定し，前もってポテ ンシャル解析で求めて抒いた流速（U）を使って，(1) Kármán の運動量方程式，（2）抵抗則を 連立で解くこ とにより，段落流の底面せん断力を求めようとするもの である。

\section{（1）境界層方程式}

本研究に掠いては，不等流に対して，Kármán の仮 定に従う式（11）を利用する。その式（11）を誘導する ために，図一6(d) の（3)で示す流れの場を想定する，そ の場では, 水梁 $(h)$ 上りさらに上方まで一様流れ（流速 は $\left.U^{\prime}\right)$ がある. 重力による質量力を考慮に入れて， $x$ 方向の運動方程式は，

$$
u \frac{\partial u}{\partial x}+v \frac{\partial u}{\partial y}=g \sin \beta-\frac{1}{\rho} \frac{\partial p}{\partial x}+\nu \frac{\partial^{2} u}{\partial y^{2}}
$$

で表わされる. ここで， $u, v, p$ はそれぞれ想定した場 での $x$ 方向の流速, $y$ 方向の流速, 圧力を表わし, $\nu$ は 渦動粘性係数を含むものとする. また, $\tan \beta$ が水路床 勾配である. $y$ 方向の運動方程式は

$$
-g \cos \beta-\frac{1}{\rho} \frac{\partial p}{\partial y}=0
$$

である。

いま, $p^{\prime} / \rho$ をピエゾ水頭とすれば, $p^{\prime}=p+\rho g y \cos \beta$ であり, $\frac{\partial p^{\prime}}{\partial y}=\frac{\partial p}{\partial y}+\rho g \cos \beta$ となる.

Kármán の仮定は $\partial p / \partial y=0$ であるが，この仮定を 重力の場で考えるならば， $\partial p^{\prime} / \partial y=0$ といらことであ る. $\partial p^{\prime} / \partial y=0$ ならば, $-\partial p / \partial y-\rho g \cos \beta=0$ となり， 式（8）と同一の式となる，つまり，式 (8) は重力を考 慮した Kármán の仮定， $\partial p^{\prime} / \partial y=0$ を示している.ま た実際の段落流においても，底面付近では，流線に曲が りがないので，そこでのピエゾ水頭は一定と考えてよ い.すなわち， $\partial p^{\prime} / \partial y=0$ を表わす式（8）は，実際の 底面付近の流れとも適切に対応している。

連続の式は

$$
\frac{\partial u}{\partial x}+\frac{\partial v}{\partial y}=0
$$

となる。

いま想定している流れの場において，境界層の外側で はベルヌーイの定理が成り立つから，

$$
-g \sin \beta+U^{\prime} \frac{\partial U^{\prime}}{\partial x}+\frac{1}{\rho} \frac{\partial p_{e}}{\partial x}=0 \cdots \cdots(10 \cdot \mathrm{a})
$$

となる.ここに， $U^{\prime}$ は先に記したように，上層の一様 流れの速度, $p_{e}$ は上層, すなわち境界層の外側の流れ の圧力である. 想定した 流れの境界層内部では $\partial p^{\prime} / \partial y$ $=0$ であり, 境界層外縁の $p_{e}$ と $p$ は等しくなる.ゆ えに,

$$
-g \sin \beta+U^{\prime} \frac{\partial U^{\prime}}{\partial x}+\frac{1}{\rho} \frac{\partial p}{\partial x}=0 \cdots \cdots \cdots(10 \cdot \mathrm{b})
$$

となり, 式 (10・b) を式 (7) に代大し, 十分に深い水 深まで積分すると，

$$
\frac{\partial}{\partial x}\left(U^{\prime 2} \theta\right)+\delta^{*} U^{\prime} \frac{\partial U^{\prime}}{\partial x}=\frac{\tau_{0}}{\rho}
$$

$\theta$ : 運動量厚, $\delta^{*}$ : 排除厚,

$$
\tau_{0} \text { : 底面せん断力 }\left(=\nu \frac{\partial^{2} u}{\partial y^{2}}\right)
$$

で示される運動量方程式を得る ${ }^{8)}$.なお, $U^{\prime}$ は以後, $U$ で表わす. その妥当性については（3）で詳述する.

ここで，流速分布としてべき乘則，

$$
u(y)=U\left(\frac{y}{\delta}\right)^{1 / n}
$$$$
\delta: \text { 境界層厚 }
$$

が成り立つと考えることにより式（11）は

$$
\frac{n}{(n+1)(n+2)} U^{2} \frac{\partial \delta}{\partial x}+\frac{3 n+2}{(n+1)(n+2)} U \delta \frac{\partial U}{\partial x}
$$




$$
=\frac{\tau_{0}}{\rho}
$$

と変形でき, 式 (13) と抵抗則を連立させることにより, $U$ の值を知れば $\delta$ と $\tau_{0}$ を求めることができる.

なお，本解析は，ポテンシャル流と境界層とを組み合 わせて底面近傍の流れを解析しようとするのであるが， 境界層が存在するため，本文で取り扱ら方法では，実際 の流れの流量の連続条件を満足しなくなっている. こう いった欠点を取り除くためには，前報6)で述べたように， 本文で求められる境界層の排除厚を算出し, 縦断方向全 域にわたって排除厚分だけ底上げして, ポテンシャル解 析を行い，その結果を用いて境界層を解析することによ り解決される。しかし，段落流の場合には境界層厚が全 体の流れに対し，相当薄いので，本文ではこの影響を無 視したが，境界層の発達の著しい場合には，排除厚を考 慮すべきであると思われる。

\section{（2）抵 抗 則}

a) 滑面の場合

滑面で， $\frac{1}{7}$ 乗則の流速分布をもつ乱流の摩擦損失係数 $f$ は，ブラジウスの実験公式

$$
\begin{gathered}
f=0.3164(\bar{u} D / \nu)^{-1 / 4} \ldots . \\
\bar{u}: \text { 平均流速, } D: \text { 管径 }
\end{gathered}
$$

で表わされる．開水路の場合， $\delta=D / 2$ とおいて，せん 断力の式を整理すると，

$$
\begin{gathered}
\frac{\tau_{0}}{\rho}=0.0225 U^{2}(U \delta / \nu)^{-1 / 4} . \\
U: \text { 最大流速 }
\end{gathered}
$$

となる。

b） 粗面の場合

一方，粗面での完全乱流領域において， $f$ は，

$$
f=C_{1}\left(k_{s} / D\right)^{1 / C_{2}}
$$

$C_{1}, C_{2}$ : 定数, $k_{s}$ : 相当粗度

と表わされる.ムーディ図表を参照して, 大きなレイノ ルズ数に対しての係数 $C_{1}, C_{2}$ を求めると, 近似的に

$$
\begin{gathered}
k_{s} / D \leq 2 \times 10^{-3} \text { のとき } \\
C_{1}=7.76 \times 10^{-2}, C_{2}=4.95 \\
k_{s} / D>2 \times 10^{-3} \text { のとき } \\
C_{1}=1.22 \times 10^{-1}, C_{2}=3.12
\end{gathered}
$$

となる. $C_{1}, C_{2}$ を式 (16) に代入し, 式 (15) の誘導と 同様の手続きにより，次に示す $n$ 乗則の流速分布に対す る抵抗則を得る.

$$
\frac{\tau_{0}}{\rho}=\left\{\frac{2 n^{2}}{(n+1)(2 n+1)}\right\}^{2} U^{2} \frac{C_{1}}{8}\left(\frac{2 \delta}{k_{s}}\right)^{-1 / C_{2}}
$$

\section{（3）底面せん断力の近似計算法}

流線に急激な曲がりを生じる段落流では，圧力分布を
静水圧分布とみなして求めた式（11）の運動量方程式で 流れを厳密に表現することはできなくなる，しかし，従 来の研究でもって，実用上十分な精度で流れ全体を知る ことができる．著者らは，底面せん断力をできるだけ正 確に求めようといら立場にたち, そのためには，底面近 傍の薄い層の 流れの状態がわかれば十分であると 考え る.そこで，(1) において述べたような流れの場を想定 して, 式（11）に基づいた底面近傍の流れの解析を行う (図一6(d) 参照).

想定した流れの場においては, すでに述べた条件に加 え,

○ 式（12）で表わしたように，流速分布はべき乗則 に従う. そして, 心゙き数 $n$ は流れの流下方向全域にわた って，同じとみなす（この仮定は著者らの実験範囲では 正しい).

○ 境界層外縁において, 主流速 $U^{\prime}(x)$ をもつ. 段 落点より十分上流では，流れは等流であり，そこでは $U^{\prime}(x)$ は表面流速と一致し, 境界層厚 $\delta$ は水深と一致 する.

以上のように想定した流れの場における $U^{\prime}, \delta$ は式 （11）を満たすが, 実際の段落水流場でのそれとは上流の 等流部分以外においては等しくないことを断っておく.

ここでの目的である底面せん断力の算定は, 滑面に対 しては, 式 (13) と式 (15), 粗面に対しては, 式 (13) と式（17）を連立させ，それぞれの点で， $U^{\prime}$ を適切に 定めて逐次計算を行らことにより算出できる.

なお， $U^{\prime}$ としてポテンシャル解析による底面の流速 $U$ を用いることの妥当性について，図一6(d) で説明を 加えておく.

図一6(d) に抒いて,

(1) は実際の流速分布

(2) はポテンシャル解析による流速分布

(3) は遠心力等を受けていない，ここで想定した流れ の流速分布 を示している。

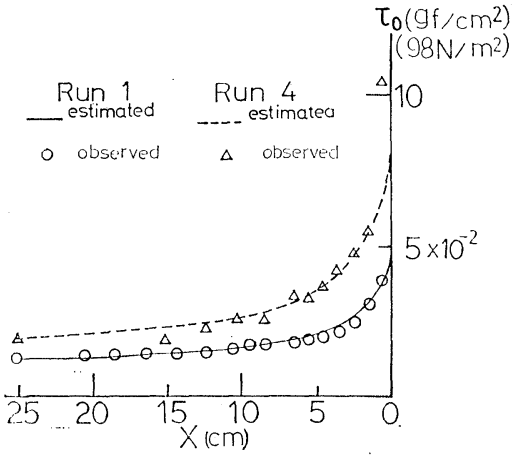

図一5 底面せん断力縦断面内分布（2） 
すなわち, ポテンシャル流 (2) では水路底面が一つの 流線になっており, その流線に沿っての流速を 0 とした ときの底面付近の流れが，いま求めたい流れである.い まの場合には，底面付近の流線は直線であり，この付近 の流管に対しては, 外加ら力は重力以外には作用しな いから， $\partial p^{\prime} / \partial y=0$ である. $\partial p^{\prime} / \partial y=0$ と仮定した流 れは, ポテンシャル流の底面の流速 $U$ が, $y$ 方向に一 様に分布する流れとなる.したがって，想定した流れの $U^{\prime}$ として, ポテンシャル流 (2) の底面流速 $U$ を用いる ことは適当である.

言い換えれば， $U^{\prime} に U$ を用いた Kármán の運動量 方程式に見合う境界層分布に, 流線の曲がりによる遠心 力が働いて, $\partial p / \partial y \neq 0$ の実際の流れ (1) が生ずるこ とになるが，底面付近ではこの $\partial p / \partial y$ がほとんどない ため, 近似的には (3) が底面近傍での実際の流れを表わ すものと考えてよい.

なお， $\delta$ はこのような流れにおいては, 式 (13) によ り上流から逐次求めることができる.

このようにして算出された $\tau_{0}$ を図一5に実測值とと もに示す. 図一5 は図一4 亿比べて実測值と計算值はよ く合致しており, この方法が近似解法として, かなり精 度のよいものであることがわかる.

\section{（4）近似計算法の検討}

せん断力を求める (3) の方法の妥当性は, 前に述べ たように, Navier-Stokes の式に戻って検討する必要が ある.これを解析的に解くことは困難であるから，圧力 の項に着目し, 想定した流れと, 実際の流れとの差を Navier-Stokes の式で調べて, 本解析法が妥当か否かを 検討する:

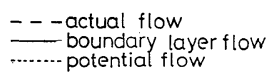

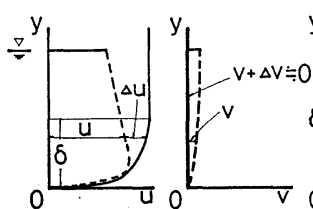

(a)

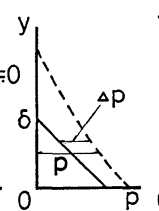

(c)

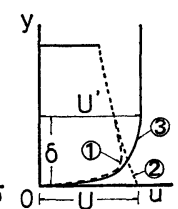

(d)
図一6 $u, \Delta u, v, \Delta v, p, \Delta p$ の定義図

流速, 圧力は図一6のように表わす。ここでは, 実 際の流れの場合は $u, v, p$ とし, 想定した場合では, そ れぞれ, $u+\Delta u, v+\Delta v, p+\Delta p$ とする.

Navier-Stokes 式中の $y$ 成分の方程式

$$
u \frac{\partial v}{\partial x}+v \frac{\partial v}{\partial y}=-g \cos \beta-\frac{1}{\rho} \frac{\partial p}{\partial y}
$$

は底面付近以外では, $v \ll U$ ではないため省略するこ とはできない, すなわち, 式 (18) の左辺の 2 つの項は
無視することができず, $y$ 方向の圧力分布は静水圧分布 でなくなる、ポテンシャル流の計算から求められる圧力 を式（18）に代入して, 前述の境界層方程式と連立して 解いて $u, v$ を求めることができれば, 同時にせん断力 活を合理的に求めることができる. しかし，これは困 難であるので, ここでは次のように考えて，ここで想定 した流れが妥当なものであるかどうかを検討する.すな わち, 実際の流れでは $\partial p^{\prime} / \partial y \neq 0$ であり, $y$ 方向に力 が作用して 図一6(d) の (1) の流速分布になっているが, ここで想定した流れでは $\partial p^{\prime} / \partial y=0$ としている. 想定 流に式 (18) を満足させる $p$ が働いたとき, 実際の流 れ (1) になるなら, 想定流は, 実際の流れの $\partial p^{\prime} / \partial y=0$ のところ,すなおち, 底面近傍の流れを近似していると いえる. そこで想定された流れでもって, 式 (18) を満 足させるために必要とされる力を考える. この力が実際 の流れの中の圧力と等しくなるか否かを, 実測の $u, v$ および，想定された流れの $u+\Delta u, v+\Delta v$ を用いて検討 する. 換言すれば, 想定された流れ (3) に, 両者の圧力 差 $\Delta p$ を加えれば, 想定された流れ (3) の $u+\Delta u, v+$ $\Delta v$ が実際の流れ (1) の $u, v$ を表わすことになると考 えてよいであるら.式（18）を想定した流れの場に対し て適用すると，

$$
\begin{aligned}
(u+\Delta u) \frac{\partial(v+\Delta v)}{\partial x}+(v+\Delta v) \frac{\partial(v+\Delta v)}{\partial y} \\
=-g \cos \beta-\frac{1}{\rho} \frac{\partial(p+\Delta p)}{\partial y} \cdots \cdots \cdots \cdots . . .
\end{aligned}
$$

となりさらに変形すると，

$$
\begin{aligned}
\left(u \frac{\partial v}{\partial x}\right. & \left.+v \frac{\partial v}{\partial y}\right)+\left(\Delta u \frac{\partial v}{\partial x}+\Delta v \frac{\partial v}{\partial y}\right) \\
& +\left\{(u+\Delta u) \frac{\partial \Delta v}{\partial x}+(v+\Delta v) \frac{\partial \Delta v}{\partial y}\right\} \\
= & -g \cos \beta-\frac{1}{\rho} \frac{\partial p}{\partial y}-\frac{1}{\rho} \frac{\partial \Delta p}{\partial y} \ldots \cdots
\end{aligned}
$$

となる。一方, 実際の段落水流に対しては, 式 (18) が そのまま, 成立している.なお, 想定された流れでは, $v+\Delta v \fallingdotseq 0$ と仮定していることを考慮して, 式 (18) と 式 (20)より，2つの流れの差を求めると,

$$
\frac{\partial \Delta p}{\partial y}=\rho\left(u \frac{\partial v}{\partial x}+v \frac{\partial v}{\partial y}\right)
$$

となる. 式 (21) に実測值 $u, v$ を代入することにより, $\partial \Delta p / \partial y$ の值は計算できる. しかし， $p$ の分布は基隻值 を与えないと求まらないので, 便宜上, $y=\delta$ の点の実 測値 $p$ の值より, 水深方向に計算して式 (21) の妥当 性, すなわち, 想定した流れの妥当性を調べる. そのよ らにして求めた静圧の計算值が, 図一7 において点線で 示されている. 図一7 では, 実際の段落水流の静圧分布 と, 計算された静圧分布はほぼ似かよった形状を示して 抢り, $U^{\prime}$ として, ポテンシャル解析による底面流速 $U$ 
を用いることの妥当性が 確認でき, $y$ 方向の圧力 を静水圧分布とみなした 式（11）を使用して，実 際の流れを, 底面近傍で は解析できることがわか る.ここで, $\partial \Delta p / \partial y$ は 底面のごく近傍では非常 に小さいため, 対数則と みなせる流速分布領域が 存在すると考えることが できるが，段落点ごく近

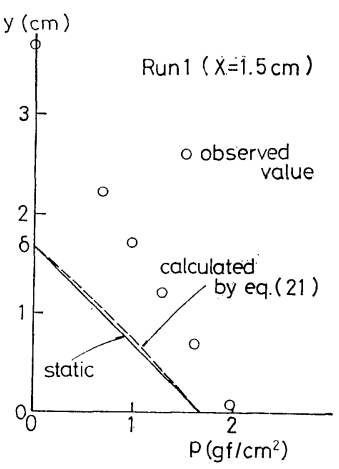

图一7压力分布
傍においては， $\partial \Delta p / \partial y$ は底面近傍において子無視で きず，流線の曲がりが激しい粗面の場合， $\tau_{0}$ の計算値 に影響を及ぼすむのと思われる。

\section{5. 段落ち部上流の平衡河床形状}

移動床の段落ち部上流においては，底面せん断力が綐 断方向に一様でないため, 河床に洗掘, 堆積を生ずる. 上流からの給砂がある場合には，平衡な河床形状がそれ ぞれの流量，給砂量により定まるものと考えられる。ま ず，この平衡状態に打ける水面形状，河床形状，流速分 布, せん断力等を測定することにより, 平衡状態におけ る，底面に働く力のつり合い関係を調べてみる。

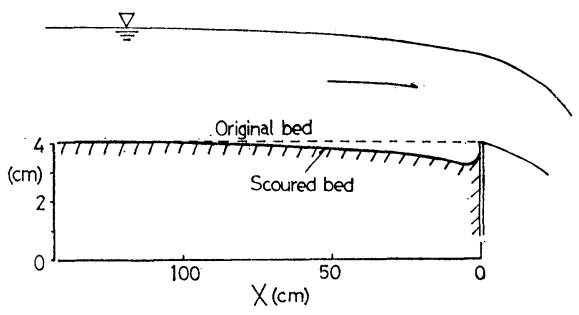

図-8 平衡河床形状

上流の等流部とみなせる場所での平衡給砂量を給砂し た場合, Run 5 では, 水路床の平衡形状は 図一8 の上 うになる. このとき, 水路床の粒子に働く, 粒子の離脱 に有効と考えられる力は，上流から下流端まで各点にお

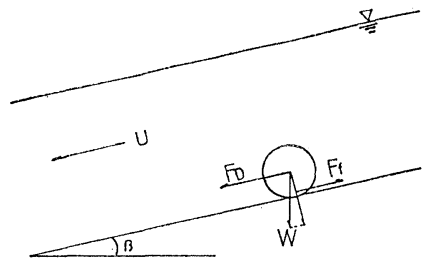

図一9 斜面上の粒子に働くカ いて等しいことが予 想される.ここで， この有効な力につい て考察を加える.図 -9 に示守傾斜角 $\beta$ の斜面上に静止して いる粒子に着目する と，粒子の離脱限界 のとき, その粒子に働く力は, 流れ方向に対して, 次の ようなつり合い関係になる。

$$
F_{D}+W \sin \beta=F_{f}
$$

$$
\begin{aligned}
& F_{D} \text { : 流体力, } W: \text { 粒子の水中重量, } \\
& F_{f} \text { : 摩擦力 }
\end{aligned}
$$

$W \sin \beta$ は重力の流れ方向成分である. 浮力の作用方向 は，段落水流のように流線に曲がりを生じている場合に は, 定めることは難しい，ここでは簡単のため, 重力と 反対方向に働くと仮定する.このとき $W$ は,

$$
\begin{aligned}
& W=\left(\rho_{s}-\rho_{w}\right) V g \\
& \rho_{s}: \text { 粒子の密度, } \rho_{w}: \text { 水の密度, } \\
& V: \text { 粒子の体積 }
\end{aligned}
$$

となる. 水路床にある粒子に働く力のつり合い関係を検 討するためには，式 (22) の各項を, 次のように単位面 積当たりの力に換算しておいた方が便利である.

平面上に粒子を密に敷いた場合，単位面積 $\left(1 \mathrm{~cm}^{2}\right)$ 当 たりに存在する粒子の数は, 粒径を $d(\mathrm{~cm})$ とすると, $1 / d^{2}$ 個であり，その体積は $\pi d / 6\left(\mathrm{~cm}^{3} / \mathrm{cm}^{2}\right)$ となる.す なわち, 重力の流れ方向成分は

$$
\tau_{g}=(\pi d / 6)\left(\rho_{s}-\rho_{w}\right) g \sin \beta
$$

で表わされ，摩擦力の項は

$$
\tau_{f}=(\pi d / 6) \mu_{1}\left(\rho_{s}-\rho_{w}\right) g \cos \beta
$$

で表わされる.ここで, 離脱限界の摩擦係数 $\mu_{1}$ は, 限 界掃流力 $\tau_{c}$ と $\tau_{f}$ を等値と考えることにより

$$
\begin{aligned}
\tau_{c} & =c\left(\rho_{s}-\rho_{w}\right) g d \cos \beta \\
& =(\pi d / 6) \mu_{1}\left(\rho_{s}-\rho_{w}\right) g \cos \beta \\
c & : \text { 定数 }(=0.05)
\end{aligned}
$$

の関係から求めることができ， $\mu_{1}=9.55 \times 10^{-2}$ となる. 流体力として実験より求めた底面せん断力， $\tau_{s}$, を用い る.さらに，有効なせん断力 $\tau_{e}$ を次のように定める.

$$
\tau_{e}=\tau_{s}+\tau_{g}-\tau_{f}
$$

段落ち部で 移動床水路末端に固定ぜきのある 場合に は, 水路床は洗掘により, 図一8 に示すように, 急な逆 勾配となる。したがって, 従来の限界掃流力の考え方に, 重力効果を加味することが必要となり，式（27）のよう な，有効な力を考えねばならなくなる．

また，水路床が洗掘された後，せきの上流側面に接し て存在する粒子のうちの最上部のものが，せきを越えて 流出しなくなったとき,すなわち, 粒子がその場にとど まって, 移動しなくなったとき, 水路床は安定する. も し，この粒子が流出したなら，その上流側の粒子は押え を失って移動し始める.こういらことが次々と上流に伝 わっていくことになると，その状態は安定床といえな い. 寸なわち, 最終的な平衡水路床は, 水路下流端の粒. 子の存在位置により上流の床高が決定されることになる 重力を加味した 実質的な 限界掃流状態 $\tau_{e}=0$ で決定さ れると考えてよい. Run 5 の実測值を用いて計算され た縦断方向の $\tau_{e}$ の分布を 図一10 に○印で示す. $\tau_{e}=$ 0 は水路床に㗢く力がっり合っている状態，すなわち式 


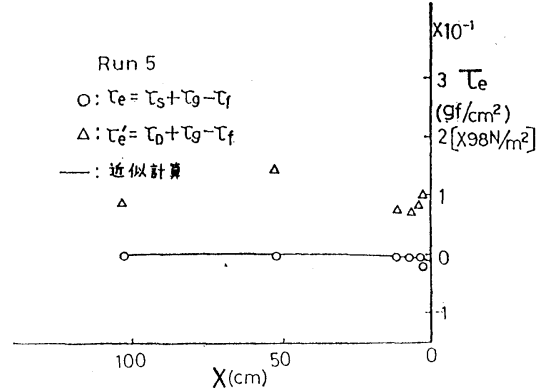

図一10 有効な力の縦断面内分布

（22）の成立する状態であり, 粒子が静止を保つ限界值 を表わす. つまり, 水路床粒子は実質的な限界掃流状態 にある. 一方, $\tau_{\boldsymbol{e}}>0$ になると粒子は移動を開始する. 図一10において， $\tau_{s}$ を用いて求めた $\tau_{e}$ の実験值が $\tau_{e}$ $\fallingdotseq 0$ を示すことから, $\tau_{e}=0$ は平衡状態というものに対 する基準となり得ることを示している，同図には，流体 力として $\tau_{s}$ でなく, 抗力 $D$ より求められた力 $\tau_{D}$ を 用いて計算した $\tau_{e}{ }^{\prime}$ を併せて記してある. なお，抗力 $D$ は, 粒径範囲内の 流速分布と, 抗力係数 $c_{D}=0.5$ の仮 定のもとに算出し， $\tau_{D}$ に換算した. そして, 摩擦係数 $\mu_{2}$ は, 球形粒子の安息角 $28^{\circ}$ (実験值) から, $\mu_{2}=0.53$ とした. 抗力を用いて求めた $\tau_{e}^{\prime}$ は, $\tau_{e}{ }^{\prime}>0$ となって おり，何らかの理由で平衡水路床より上方に位置する粒 子には，移動するのに十分な力が加わっていると判断で きる.すなわち，平均的な水路床面にある粒子（実質的 な限界掃流状態にある粒子) はこの状態では移動せず， 上流より流下移動してきた粒子は，その面より上方にあ るため，そのまま流下していくことを意味している．し かし，これは平均的な話であり，現実には河床面に多少 の凹凸があり，河床面の一部の粒子は移動を開始し，や や低い位置にある粒子の上に，上流からきた粒子が停止 するなど, 水路床粒子の交換が行われながら, 平衡形状 を保つものと考えられる.

以上より, 粒子の離脱に有効な力 $\tau_{e}$ の特性が明らか になったので, 4.(3) で提案した底面せん断力の近似計 算法を Run 5 に適用する. その結果を 図一10 に実線 で示す. ポテンシャル流としての解析の際は, 水面形状 および水路床形状に平衡河床形状での実測值を用いてい る. 計算で求められた $\tau_{e}$ の分布は実測と, よく一致し ており, 現実の砂防ダム, 床止め等の 河床形状の 解析 に，この手法が有用であることを示している.

次に, 水面形状は既知のものとして, 平衡河床形状を 推定する方法を考える. 初期条件として洗掘が生ずる前 の平坦な段落ち部上流の河床形状を与え, 流れ全体をポ テンシャル流として解析を行う. 先に提案した方法で, 底面せん断力を算出し, 式 (27) の河床の平衡条件 $\tau_{e}=$ 0 を満足する河床形状を決定する. この河床形状を用い
て, 再びポテンシャル解析を行う. この操作を繰り返 し，平衡条件を満足するようになるまで行えば，平衡河 床形状を定めることができる。

この例のよらに, 洗掘のため, 底面が曲率をもつ場合 には底面付近の境界層流れも, 流れと直角方向に力が作 用することになり， $\partial p^{\prime} / \partial y \neq 0$ となるので, 本来なら ば，境界が曲率をもつ流れとして解析しなければならな い. しかし, 本例の程度の洗掘では曲がりがわずかであ るため, 直線境界とみなし, $\partial p^{\prime} / \partial y=0$ として解析して も, 比較的精度よく洗掘形状を推定できる結果を得た. さらに, 湾曲度の大きい底面形状の場合については, 今 後検討するつもりである.

\section{6. おわりに}

固定床および移動床の段落水流の実験, およびポテン シャル流と境界層流を組み合わせた解析を行い，次のよ うな結論を得た。

（1）段落ち流における境界層の近似計算法を開発し た。

（2）この手法をポテンシャル流と組み合わせること により，2 次元不等流性の強い流れの底面せん断力を精 度よく推定できるようにした。

（3）段落ち流の平衡河床形状を推定する手がかりを 与えた.

なお，本論文における解析では，実測により得られた 水面形状を用いており，水面形状を理論的に得ることが できれば，底面せん断力および河床形状の推定に，非常 に，有効な手法 となる．Fr 数が 1 以上の段落水流に対 しては Markland の方法, Rouse の水面形状等を用い ることにより，水面形状の概略を推定することが可能で ある.しかし，Fr 数が 1 以下の段落水流に対しては， ナップの形状のみが，岩崎式により得られるのみであ り, 静圧が静水圧分布でないため, 水面形計算が困難と なっている. 現在考えられる水面形推定法としては, 実 験例等から, 縦断方向の圧力補正係数を推定し, それを 用いて水面形計算を行い, その水面形状を用いてポテン シャル流として解析し, 圧力補正係数を求め, 再び水面 形計算を行い, 最終的に用いた圧力補正係数と, 求めら れた圧力補正係数が一致するまで計算を繰り返す等の方 法が考えられるが, 非常に手数がかかり，精度にも疑問 がもたれる. 今後, この方面に対する研究がなされ, よ り精度よく底面せん断力および河床形状の推定がなされ ることを期待したい.

最後に, 本研究において多大なご助力をいただいた中 国電力（株）田中 等氏に深甚なる謝意を表します. 


\section{参 考 文 献}

1) Rajaratnam, N. and D. Muralidhar : Characteristics of the rectangular free overfall, J. Hydraulic Research, 6, pp. 233 258, 1968.

2) Rouse, H. : Discussion of "Energy loss at the base of a free overfall”, Trans. ASCE, Vol. 109, pp. 1383 1387, 1943.

3）岩崎敏夫 : 段落水流の 水理現象に関する 実験的考察，士 木学会誌 38-6, pp. 241 246, 1953.

4) Southwell, R. and G. Vaisey : Relaxation method applied to engineering problems. XII. Fluid motions characterized by 'Free' stream-lines, Phil. Trans. Series
A, Vol. 240, 1946-11.

5) Markland, E. : Calculation of flow at a free overfall by relaxation method, Proc. of the Institution of Civil Engrs. England, No. 686, 1965.

6）吉川秀夫・片山道夫・田中 等・福井吉孝 : 段落ち部の 水理, 第 26 回水理講演会論文集, pp. 673 678, 1982.

7) Preston, H. : The determination of turbulent skin friction by means of pitot tubes, J. Roy, Aero, Soc., Vol. 54, 1954.

8）日野幹雄 : 流体力学, 朝倉書店, 1974. 